\title{
Pelatihan Java Fundamental di SMKN 1 Balikpapan
}

\author{
Aswadul Fitri Saiful Rahman ${ }^{1, *}$, Muhammad Irfan ${ }^{1}$, Imam Muslimin ${ }^{1}$ \\ ${ }^{1}$ Fakultas Teknologi Industri; Universitas Balikpapan; I. Pupuk Raya, Gn. Bahagia, Balikpapan \\ Selatan, Balikpapan; e-mail: aswadul864@uniba-bpn.ac.id, imammmuslimin18@gmail.com. \\ muham28.irfan@gmail.com. \\ * Korespondensi: e-mail: aswadul864@uniba-bpn.ac.id
}

Submitted: 10/01/2022; Revised: 17/01/2022; Accepted: 24/01/2022; Published: 31/01/2022

\begin{abstract}
SMK Negeri 1 Balikpapan is one of the favorite vocational schools in the Sepinggan village, South Balikpapan. In the era of the industrial revolution 4.0 which is increasingly developing, technology is increasingly influential in every life, including in the world of education. From these considerations, an idea arose to provide Fundamental Java programming training to students of SMK Negeri 1 Balikpapan to be equipped as Java programmers who are reliable and able to compete in the world of work. This training was held at SMKN 1 Balikpapan in the IT department which includes TKJ and RPL. The training was carried out for 2 days by a lecturer in Electrical Engineering at the University of Balikpapan. Students directly practice with their respective computers or laptops, In the project session, they succeeded in making project programs individually and in groups.
\end{abstract}

Keywords: Java Fundamentals, Programming, SMKN 1 Balikpapan, Training

\begin{abstract}
Abstrak
SMK Negeri 1 Balikpapan merupakan salah satu sekolah favorit kejuruan yang ada dikelurahan sepinggan, Balikpapan selatan. Diera revolusi industri 4.0 yang semakin berkembang membuat teknologi semakin berpengaruh dalam setiap kehidupan, termasuk pada dunia pendidikan. Dari pertimbangan tersebut, maka timbul sebuah gagasan untuk memberikan pelatihan pemrograman Java Fundamental kepada siswa-siswi SMK Negeri 1 Balikpapan untuk menjadi bekal sebagai programer java yang handal dan mampu bersaing didunia kerja. Pelatihan ini dilaksanakan di SMKN 1 Balikpapan pada jurusan TI yang meliputi TKJ dan RPL. Pelatihan dilaksanakan selama 2 hari oleh dosen dan mahasiswa Teknik Elektro Universitas Balikpapan. Siswa-siswa secara langsung melakukan praktek dengan komputer atau laptopnya masingmasing, disesi project mereka berhasil membuat project program secara individu dan kelompok.
\end{abstract}

Kata kunci: Java Fundamental, Pemrograman, SMKN 1 Balikpapan, Pelatihan

\section{Pendahuluan}

SMK Negeri 1 Balikpapan merupakan salah satu sekolah favoritkejuruan yang adadikelurahansepinggan, Balikpapan selatan. Era revolusi industri 4.0 yang semakin berkembang menuntut masyarakat untuk mampu dalam bidang teknologi baik dalam masyarakat maupun dalam lingkungan Sekolah. Untuk lingkungan sekolah sendiri harus mengikuti perkembangan tersebut dengan cara memberikan pelatihan atau praktek secara langsung seperti dalam pemrograman bahasa java dengan aplikasi android. Android merupakan aplikasi yang berbasiskan pemrograman java (Yener, Murat et al, 2016). Berkembangnya teknologi di lingkungan sekolah menuntut kami untuk ikut dalam kontribusi 
dalam hal peningkatan teknologi terutama dalam pelatihan pemrograman java Fundamental kepada siswa-siswi SMK Negeri 1Balikpapan. Pelatihan java ini diharapkan menjadi salah bekal bagi siswa-siswi untuk bisa menjadi programer java yang handal dan mampu bersaing didunia kerja. Berkarir sebagai programer java merupakan salah satu pilihan bagi peminat siswa jurusan rekayasa perangkat lunak atau IT karena peluang kerja yang besar menjadi cara dalam menghadapi era revolusi industri 4.0. Pelatihan ini akan mengenalkan tentang konsep dalam pemrograman Java Fundamental dan praktek pemrograman serta tips cara membuat aplikasi.

Program Kerja yang kami lakukan ini merupakan pelatihan java fundamental untuk siswa SMKN 1 Balikpapan.Inimerupakan bekal untuk siswa TI setelah lulus sekolah dan mampu untuk memasuki dunia kerja. Disampingitu, dalampelaksanaanpelatihan java fundamenta ini kami juga membuat kelompok kecil untuk membuat dan mengembangkan project aplikasi java. Project tersebut dipresentasikan per kelompok. Pelatihan ini dilaksanakan di SMKN 1 Balikpapan dikerenakan sekolah ini memiliki jurusan TI yang meliputi TJK dan RPL. Selama ini dalam teori kelas tentang pemrograman java atau berbasis object oriented masih dirasa kurang. Sekolah ini merupakan sekolah kejuruan yang paling banyak peminatnya di kota balikpapan.

Pemrograman merupakan kegiatan yang dilakukan oleh programmer dalam membuat kode dalam bahasa tertentu (John, Bullinari, 2019). Java merupakan bahasa yang banyak dipakai dalam aplikasi di era ini. Bahasa ini mempunyai beberapa aplikasi yang dikembangkan antara lain mobile, platform desktop, loT, Embedeed dll (B, Jeanne, S, 2015). Bahasa ini mampu berjalan diberbagai sistem operasi dan bersifat free, konsep yang digunakan yaitu bahasa pemrograman berbasis object (OOP)(B, Jeanne, S, 2016), dengan OOP pengembang akan lebih mudah dalam mengembangkan aplikasinya serta bahasa java memiliki library yang memudahkan pengembang dalam membuat aplikasi (Schildt, 2014). Aplikasi native yang banyak dikembangkan sekarang ini adalah java, sebagian besar masyarakat menggunakan telepon berbasis program Android (Schildt, 2011). Java banyak digunakan oleh pengembang aplikasi dan juga banyak dipelajari oleh mahasiswa-mahasiswa perguruan tinggi serta siswasiswa sekolah. Di era ini banyak perusahaan membuat aplikasi untuk mendukung pekerjaan mereka, salah satu yang banyak di kembangkan yaitu java, menguasai java akan menjadi keuntungan yang lebih disaat bersaing dalam dunia kerja.

Java mempunyai beberapa konsep umum yaitu statement, variabe/ dan data tipe serta percabangan (if-else, switch) dan yang terakhir ada perulangan (for, while) (Lecessi, 2019) (Mcgeoch, 2012). Dalam mempelajari bahasa java yang berorientasi object kita harus memahami anatomi kode program seperti class, package dan class member (Microsystems et al., 2013). Class terdiri dari beberapa class member, dan class member ini mempunyai beberapa jenis antara lain: Constructor, Method, Property dan Inner Class (Lewandowski, Coinvestigator and Lewandowski, 2015).

Dalam mengembangkan aplikasi atau program java, pemrogram dapat menggunakan beberapa tool yang mendukung bahasa pemrograman java untuk mempermudah dalam membuat program, tool ini memiliki beberapa kemampuan antara lain: Melakukan kompilasi 
program, Menjalankan program, Kompress folder, Pengujian, Interaksi dengan aplikasi, Melakukan penyebaran dan undeploy, on/off aplikasi server dan sebagainya (Muhardin, 2008). Beberapa tool yang bisa digunakan meliputi a) Eclipse; b) Netbeans; c) Hypersonic SQL; d) Tomcat. Eclipse adalah sperangkat lunak open source yang didukung oleh IBM dengan konsep Integrated Development Editor. Eclipse dirancang dengan berbasis plugin, sehingga banyak penyedia plugin gratis dan berbayar untuk pengguna. Netbeans merupakan software pendukung yang open source yang dikembangkan oleh Sun Microsystem. Andalan perangkat lunak ini yaitu Engine Matisse yang dapat digunakan untuk membuat aplikasi desktop seperti pada Delphi atau VB. Hypersonic SQL merupakan DBMS untuk basis data berukuran kecil atau tidak sampai satu megabyte. Hypersonic SQL dapat berjalan sebagai server, atau secara embedded, selain itu oracle mempunya database sendiri dengan nama Oracle Database dan MySQL. Tomcat merupakan servlet engine, serta web server yang berfungsi untuk servet dan JSP, dapat diunduh di http://tomcat.apache.org.

Java adalah bahasa pemrograman berorientasi objek (OOP) dan kelas merupakan aspek penting dari OOP. Kode Java akan dieksekusi dan muncul dalam definisi kelas. Kelas menjelaskan objek, yang merupakan kata benda dalam program. Objek dapat mewakili sesuatu yang nyata, seperti televisi atau sepeda, atau dapat mewakili sesuatu yang kurang jelas tetapi sama bergunanya dalam program. Objek adalah turunan dari kelas, seperti cetak biru untuk sebuah rumah, dan objek sebagai rumah. Sebagai permulaan, kelas Java harus didefinisikan dalam file teks dengan ekstensi .java. Selain itu, jika kelas dideklarasikan public, maka nama file harus sesuai dengan nama kelas. Java mengizinkan beberapa kelas dalam satu file .java selama tidak lebih dari kelas diatasnya yang dideklarasikan sebagai publik.

Package adalah pengelompokan kelas dan antarmuka, dapat berisi enumerasi dan tipe beranotasi, tetapi karena ini adalah tipe khusus dari kelas dan antarmuka, maka bisa merujuk ke item dalam sebuah paket hanya sebagai kelas dan antarmuka. Pengelompokan kelas dan antarmuka ini biasanya didasarkan pada hubungan dan penggunaannya.

Aplikasi Java berisi dua jenis data: tipe primitif dan tipe referensi, keduanya mempunyai perbedaan terutama dalam garbage collection. Java memiliki delapan tipe data bawaan, yang disebut sebagai tipe primitif Java. Kedelapan tipe data ini mewakili blok untuk objek Java, karena semua objek Java adalah sebuah kumpulan yang kompleks dalam memori tipe data primitif. Tipe primitif dialokasikan dalam memori yang sudah dideklarasikan pada program. Tipe referensi merupakan variabel yang berupa tipe kelas, tipe antarmuka, dan tipe array. Sebuah referensi mengacu pada sebuah objek (sebuah instance dari sebuah kelas). Tidak seperti tipe primitif yang memegang nilai dalam memori tempat variabel dialokasikan, referensi tidak menyimpan nilai objek yang dirujuk. Sebagai gantinya, referensi "menunjuk" ke suatu objek dengan menyimpan memori alamat dimana objek berada, suatu konsep yang disebut sebagai pointer. Namun, bahasa Java tidak mengizinkan programmer untuk mengakses alamat memori fisik dengan cara apa pun, jadi meskipun referensi mirip dengan pointer, Anda hanya dapat menggunakan referensi untuk mendapatkan akses ke bidang dan metode yang mengacu oada 
objek. Tidak mungkin untuk menentukan alamat sebenarnya yang disimpan dalam memori variabel referensi.

Java memiliki beberapa operator untuk menjalankan operasi arimatika, operator ini memiliki prioritas berdasarkan hirarkinya.

$\begin{array}{ll}\text { Post-increment/Post-decrement } & : \text { ekspresi ++, ekspresi-- } \\ \text { Pre-increment/pre-decrement } & :++ \text { ekspresi, --ekspresi } \\ \text { Unary operator } & :+,-,, \text {,! } \\ \text { Multiplication/division/modulus } & :{ }^{*}, /, \% \\ \text { Addition/subtraction } & :+,- \\ \text { Shift operators } & :<<,>>,>>> \\ \text { Relational operators } & :<,>,<=,>= \\ \text { Equal to/not equal to } & :==, != \\ \text { Bitwise AND,exclusive OR,inclusiveOR } & : \&, \wedge, \mid \\ \text { Logical AND, OR } & : \& \&, \| \\ \text { Ternary operator } & : ?: \\ \text { Assignment operators } & :=+=,={ }^{*}=/=\% / \&={ }^{\wedge}=\end{array}$

Variabel mewakili bagian memori yang dialokasikan untuk menyimpan data. Java adalah bahasa pemrograman yang sangat kuat, artinya setiap variabel harus dideklarasikan dengan tipe data tertentu sebelum dapat digunakan. Mendeklarasikan variabel melibatkan tipe data dan memberi nama variabel. Misalnya, pernyataan berikut mendeklarasikan tiga variabel; saluran bernama int, diagonal bernama ganda, dan referensi String bernama merek :

int channel;

double diagonal;

String brand;

Sebuah variabel diinisialisasi ketika pertama kali diberi nilai. Misalnya, pernyataan berikut menginisialisasi tiga variabel:

channel = 32;

diagonal = 53.0;

brand = "Acme";

Di Java, sebuah variabel harus diinisialisasi sebelum digunakan. Variabel yang mewakili bidang di kelas secara otomatis diinisialisasi ke nilai "nol" yang sesuai selama instantiasi objek. Variabel lokal harus diinisialisasi secara spesifik. Nama variabel disebut sebagai pengenal (fields, classes, methods, interfaces, and enums are also identifiers). Berikut adalah aturan untuk identifier a) Identifier adalah urutan karakter Unicode dari huruf Java dan angka Java. Ini termasuk karakter ASCII A - Z dan a - Z , digit $0-9$, karakter garis bawah ( ), dan tanda dolar (\$); b) Karakter pertama pengenal harus berupa huruf Java, garis bawah, atau tanda dolar. (Dengan kata lain, karakter pertama tidak boleh berupa angka.); c) Pengidentifikasi tidak boleh berupa kata kunci Java, true , false , atau null . 
Java mempunyai tiga ruang lingkup variabel yang berbeda-beda. Lingkup ini mengacu pada bagian kode di mana variabel dapat diakses. Ada tiga jenis variabel di Java, tergantung pada cakupannya: a) Variabel Instance Variabel-variabel ini mewakili bidang non-statis dari suatu kelas; b) Variabel kelas Variabel ini mewakili bidang statis kelas; c) Variabel lokal Variabel-variabel ini didefinisikan di dalam sebuah metode. Variabel lokal hanya dapat diakses dalam metode di mana mereka dideklarasikan.

Variabel Instans, Variabel instans adalah bidang nonstatis dari kelas, sering disebut hanya sebagai bidang. Variabel-variabel ini dialokasikan dalam memori ketika objek baru dipakai. Karena operator baru mengosongkan memori untuk suatu objek, semua bidang awalnya memiliki nilai nol yang sesuai, yaitu sebagai berikut: a) Bidang numerik primitif diinisialisasi ke 0 . Ini termasuk byte, short, int, long, float dan double; b) tipe boolean diinisialisasi ke false; c) tipe char diinisialisasi ke karakter nol ' lu0000 '; d) tipe referensi diinisialisasi ke null.

Gambar 1 Menjelaskan tentang alur dalam penyelesaian masalah yang meliputi Indentifikasi permasalahan, Persiapan pelatihan, pelaksanaan dan pembuatan project java. Sebelum memulai kegiatan, pelaksana mengidentifikasi kebutuhan apa saja yang dibutuhkan oleh SMKN 1, setelah didapatkan identifikasi yang berupa kebutuhan pelatihan dalam pemrograman, maka langkah selanjutnya yaitu mempersiapkan alat yang akan digunakan dalam pelatihan pemrograman java fundamental, beberapa peralatannya antara lain, laptop, perangkat lunak atau netbeans, zoom meeting dan materi java fundamental. Langkah selanjutnya melakukan pelatihan java programming atau fundamental melalui daring. Langkah terakhir yaitu pembuatan project yang dilakukan oleh siswa-siswi dengan membentuk kelompok-kelompok kecil.

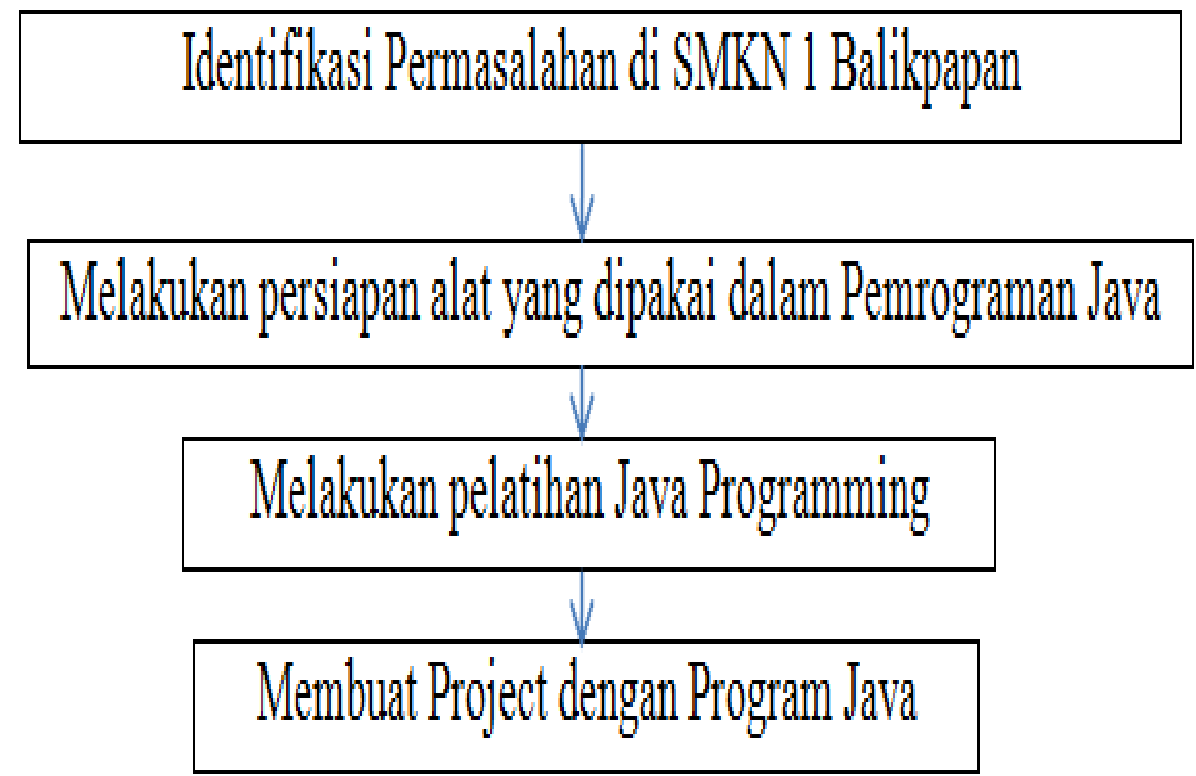

Sumber: Hasil Pelaksanaan (2021)

Gambar 1. Kerangka Penyelesaian Masalah 


\section{Metode Pelaksanaan}

\subsection{Realisasi Penyelesaian Masalah}

Pelatihan java fundamental dilakukan selama 2 hari dengan multiteaching dari dosen dan Mahasiswa Teknik Elektro Universitas Balikpapan. Pelatihan ini dilakukan secara daring dikerenakan masa pandemi. Meskipun melalui daring antusisme siswa-siswi sangat besar dan mereka sangat interaktif dalam tanya jawab tentang program dan kode program.

\subsection{Metode Pelaksanaan}

Metode yang dilakukan adalah melakukan pelatihan dengan software netbeans untuk pemrograman java fundamental. Pelaksanaan dilakukan secara daring dan langsung dipraktekkan oleh siswa. Kegiatan diikuti oleh siswa kelas XI jurusan TKJ dan RPL. SMKN 1 Balikpapan terletak di Kelurahan Sepinggan, Balikpapan Selatan.

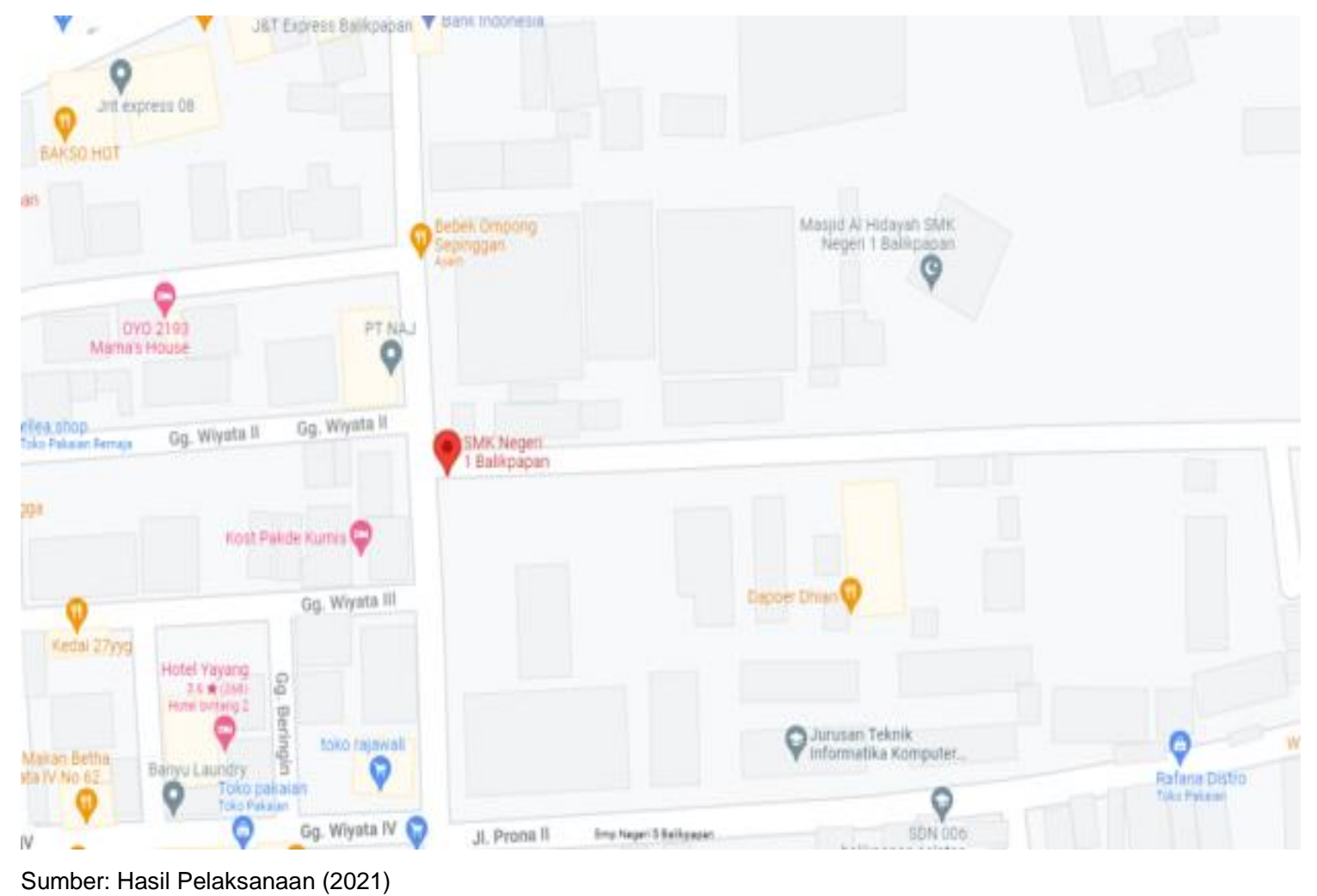

Gambar 2. Lokasi SMKN 1 Balikpapan

\section{Hasil dan Pembahasan}

Pelatihan ini dilaksanakan secara daring menggunakan aplikasi google meet, berikut dokumentasi hasil kegiatan tersebut.

\subsection{Pendahuluan tujuan kegiatan}

Gambar 3 merupakan sesi pembukaan yang digunakan untuk perkenalan antara pelaksana dan siswa-siswi SMK N 1 Balikpapan serta menjelaskan tujuan dan topik pelaksanaan pelatihan. 


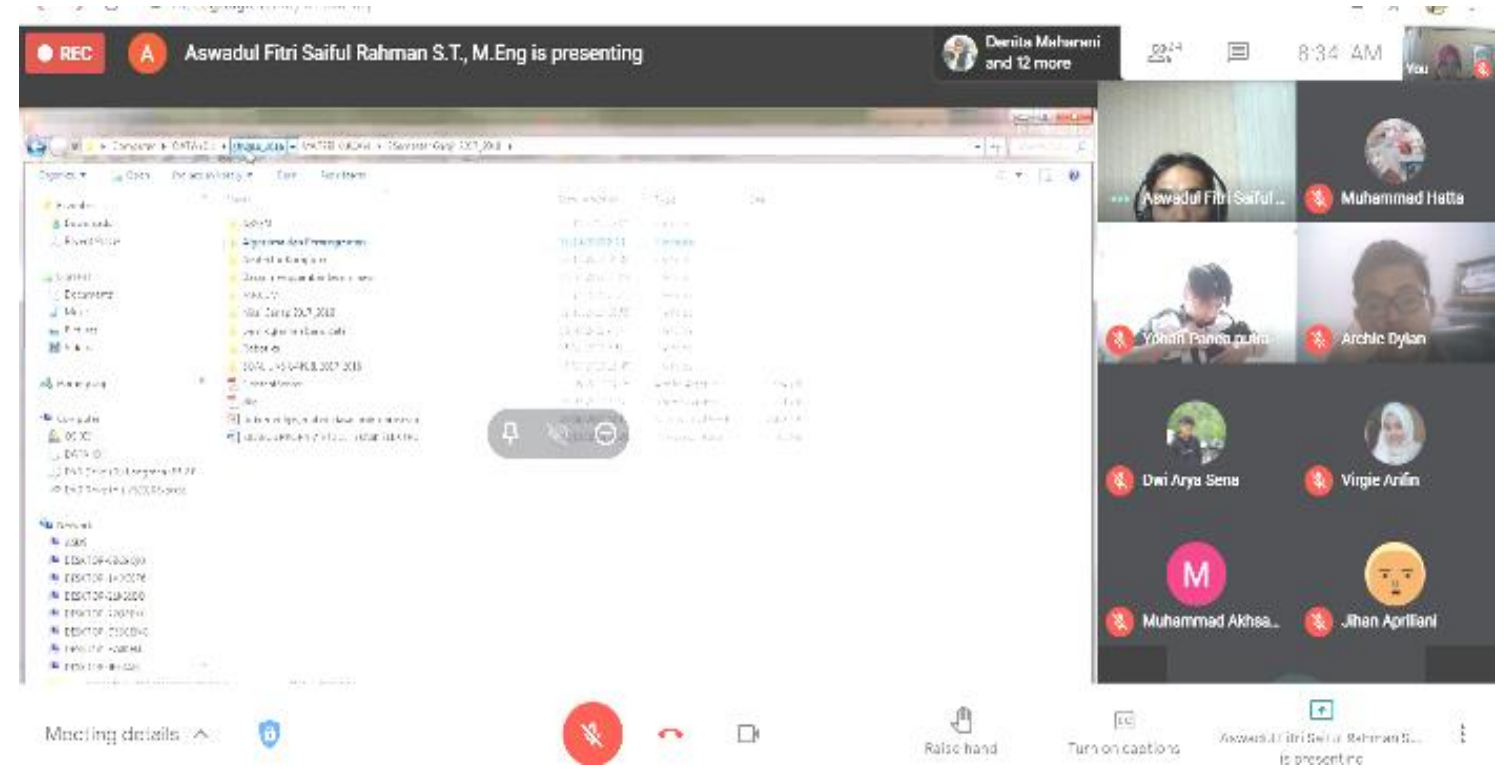

Sumber: Hasil Pelaksanaan (2021)

Gambar 3. Perkenalan antara pelaksana dan siswa

\subsection{Pelatihan}

Pelatihan melalui google meet dengan kamera on, meskipun ada beberapa yang off kamera dikarenakan koneksi yang lambat.

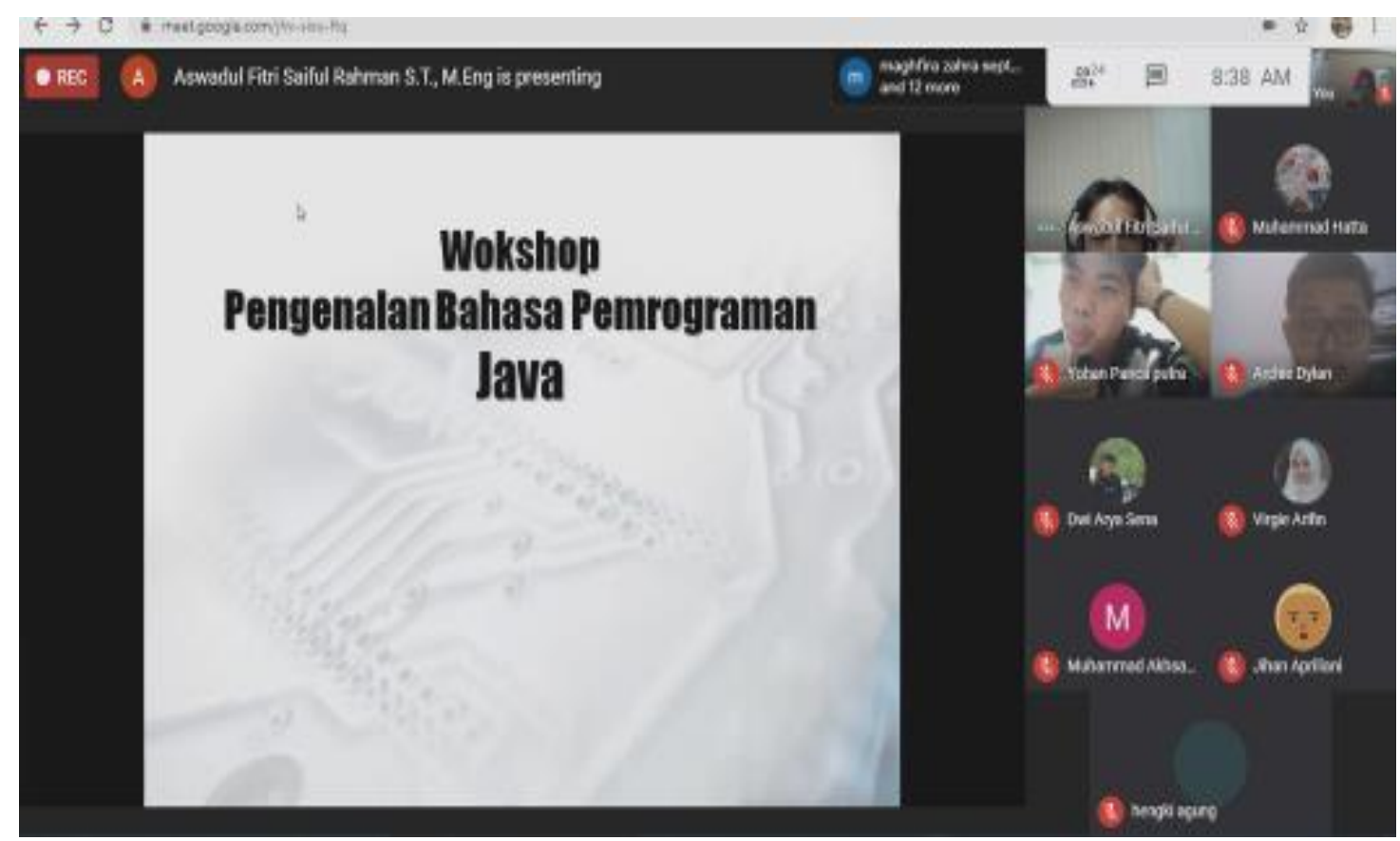

Sumber: Hasil Pelaksanaan (2021)

Gambar 4. Pelatihan dimulai dengan pengenalan Bahasa Java

Pada Gambar 4 menunjukkan tentang penjelasan bahasa pemrograman yang akan digunakan dalam kegiatan ini dan juga menerangkan sejarah singkat bahasa java. 


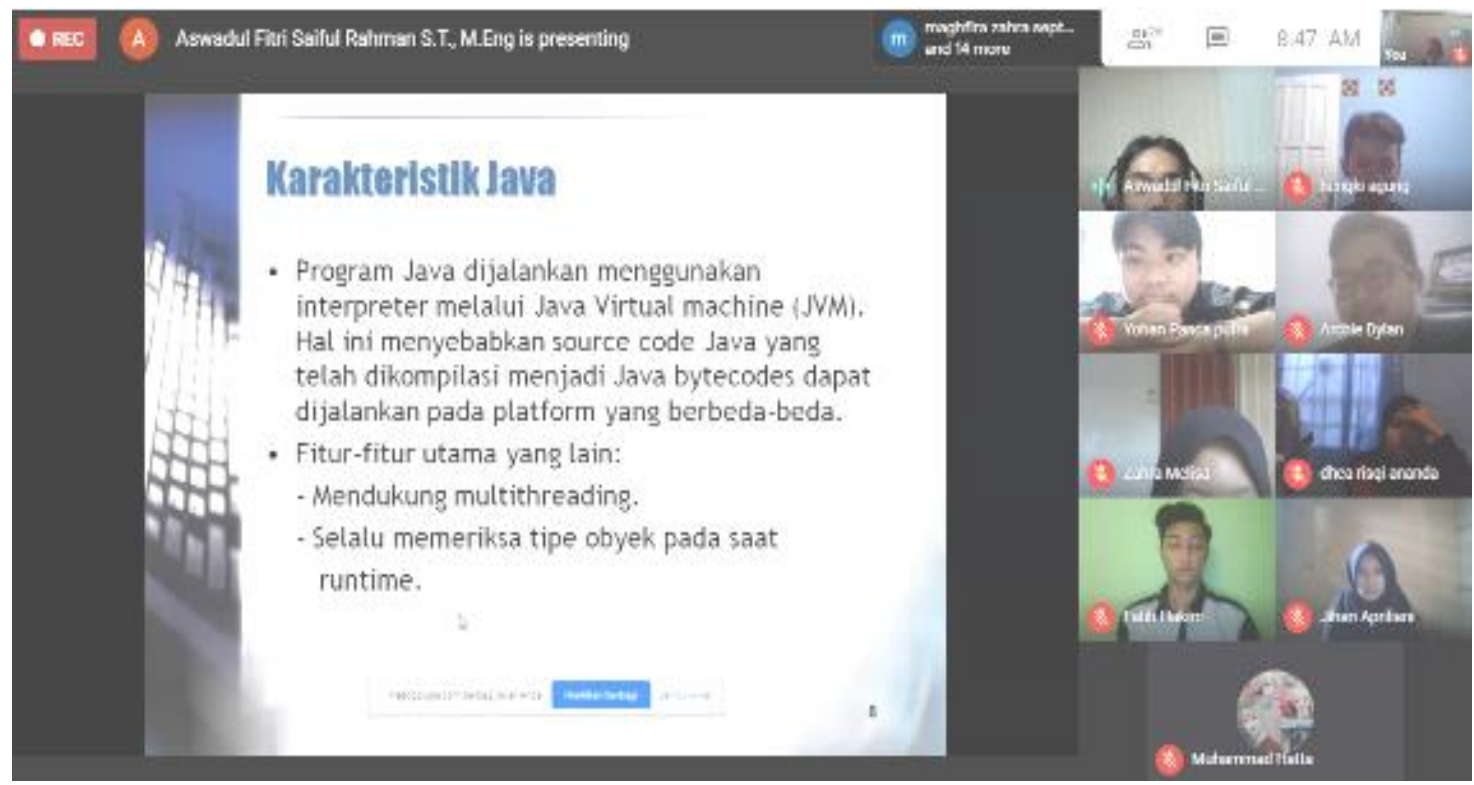

Sumber: Hasil Pelaksanaan (2021)

Gambar 5. Pemateri menjelaskan tentang karakteristik Java

Gambar 5 menunjukkan pemateri menjelaskan lebih detail lagi tentang karakteristik java yang semakin berkembang terutama di era rovelusi 4.0.

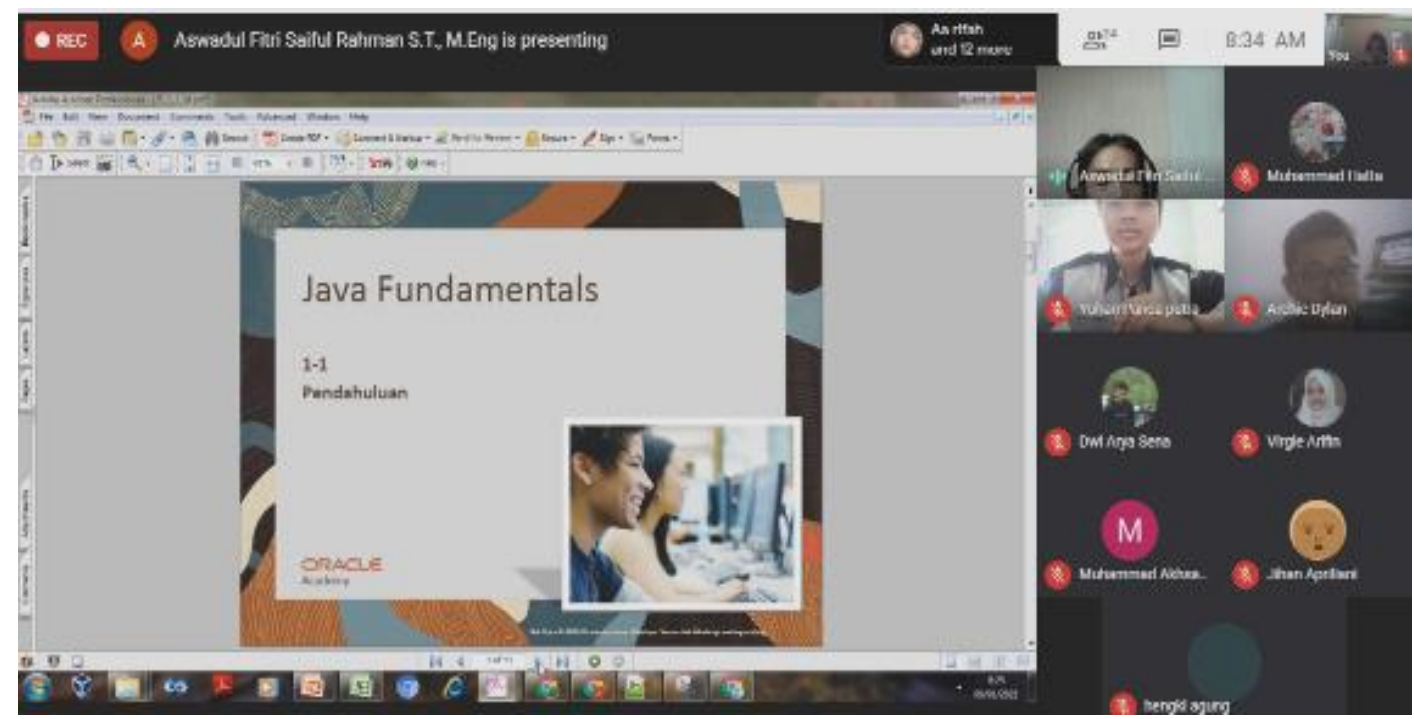

Sumber: Hasil Pelaksanaan (2021)

Gambar 6. Penjelasan Java Fundamental

Pada Gambar 6 instruktur menjelaskan tema tentang Java Fundamental, sub topik, fungsi, variable, tipe data, forecasting, inheritance dan contoh penggunaannya.

\subsection{Sesi Tanya Jawab dan Diskusi}

Setelah materi selesai disampaikan, kemudian dibuka sesi tanya jawab, diskusi beserta latihan pembuatan program atau project sederhana. 


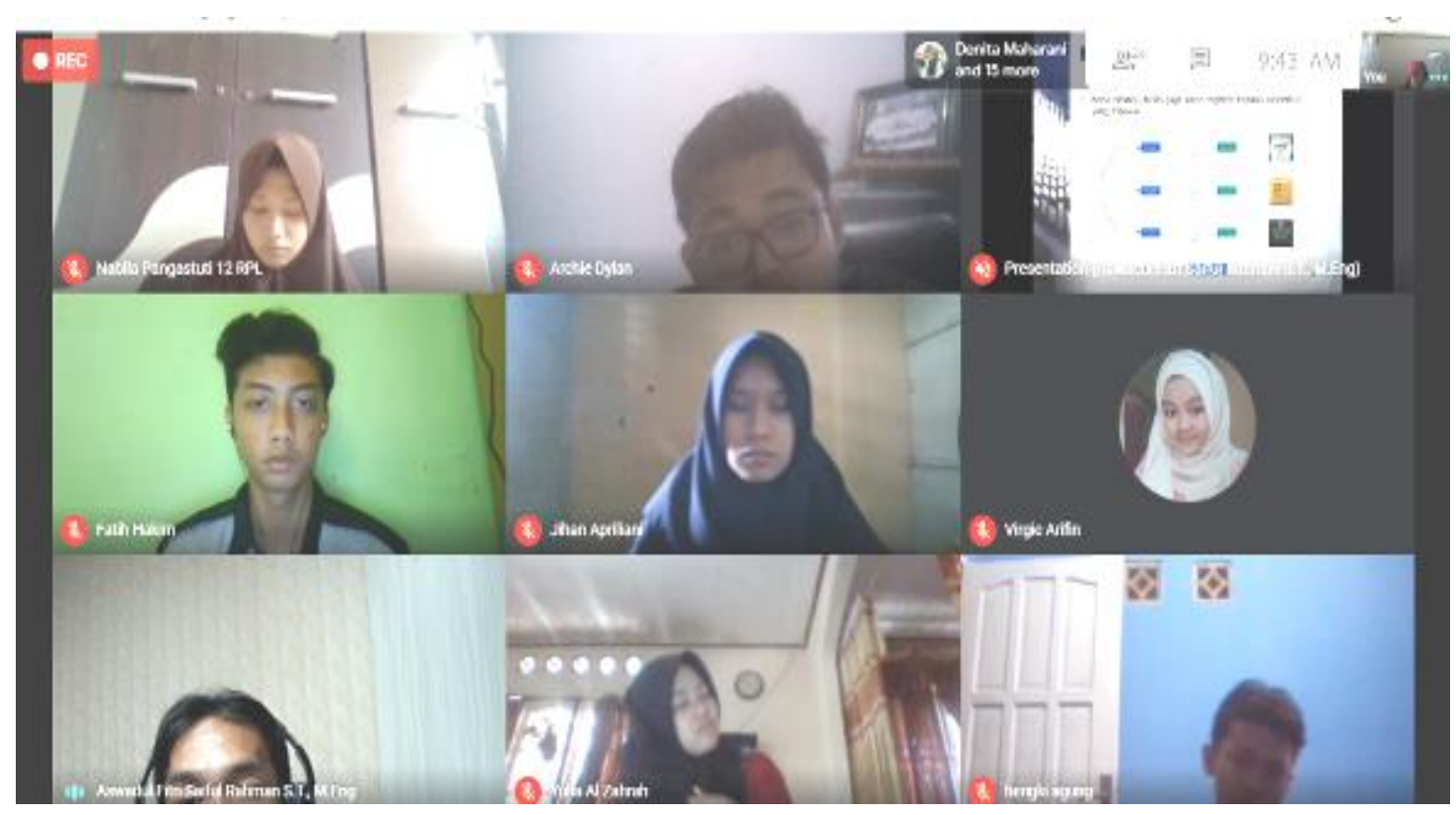

Sumber: Hasil Pelaksanaan (2021)

Gambar 7. Sesi tanya jawab, diskusi dan latihan membuat program sederhana.

Gambar 7 merupakan sesi tanya jawab dan latihan, disesi ini digunakan secara maksimal oleh siswa-siswa untuk menanyakan apa saja yang belum diketahui, serta berlatih membuat program java fundamental dengan tool netbeans.

\section{Kesimpulan}

Kegiatan pelatihan java fundamental dilakukan secara daring dengan menggunakan platform google meets. Pelaksanaan dilakukan selama 2 hari. Siswa-siswa secara langsung melakukan praktek dengan komputer atau laptopnya masing-masing. Disesi terakhir siswa-siswi membentuk kelompok sekita 3 orang untuk membuat project sederhana dan dipresentasikan. Antusisme siswa-siswi sangat besar sekali, ini terbukti dari sesi daring yang selalu mereka ikuti dari awal sampai akhir dan mereka berhasil membuat project individu dan kelompok.

\section{Ucapan Terima Kasih (Opsional)}

Terima kasih kepada Guru dan Siswa-siswi SMK N 1 Balikpapan atas kepercayaannya dalam pelaksanaan kegiatan ini dan semoga kegiatannya bermanfaat dan menunjang dalam pembelajaran di sekolah.

\section{Daftar Pustaka}

B, Jeanne, S, S. (2015) OCA Java SE 8 Programmer // Study Guide, The effects of brief mindfulness intervention on acute pain experience: An examination of individual difference.

B, Jeanne, S, S. (2016) OCP Java SE Programmer II. Available at: http://solutionsproj.net/software/Beginning_Android_Programming_with_Android_Studio.pd f. 
John, Bullinaria. (2019) Data Structures and Algorithms, University of Brimingham.

Lecessi, R. (2019) Functional Interfaces in Java, Functional Interfaces in Java. doi: 10.1007/978-1-4842-4278-0.

Lewandowski, C. M., Co-investigator, N. and Lewandowski, C. M. (2015) Java 8 in Action, The effects of brief mindfulness intervention on acute pain experience: An examination of individual difference.

Mcgeoch, L. A. (2012) 'Java TM Programming', Most.

Microsystems, S. et al. (2013) 'Java tutorialspoint: simply made easy learning'.

Muhardin, E. (2008) 'Java Fundamental ( JSE )', pp. 1-47.

Schildt, H. (2011) Java The Complete Reference Eighth Edition.

Schildt, H. (2014) Java Complete Reference, Mc Graw Hil.

Yener, Murat. (2016) Expert android Studio, John Wiley \& Sons, Inc 